\title{
A Solid-Phase Enzyme-Linked Assay for Vitamin $B_{12}$
}

\author{
Catherine D. Tsalta*, Sara A. Rosario, Geun Sig Cha, \\ Leonidas G. Bachas**, and Mark E. Meyerhoff*** \\ Department of Chemistry, The University of Michigan, Ann Arbor, MI 48109-1055, USA
}

\begin{abstract}
A new solid-phase enzyme-linked competitive binding assay for vitamin $B_{12}$ (cyanocobalamin) is described. The assay is based on the competition between analyte $B_{12}$ molecules and a glucose-6-phosphate dehydrogenase-vitamin $B_{12}$ conjugate for a limited number of R-protein binding sites immobilized on sepharose particles. After appropriate incubation and washing steps, the enzyme activity bound to the solidphase is inversely related to the concentration of $B_{12}$ in the sample. Under optimized conditions, the method can detect $B_{12}$ in the range of $3 \times 10^{-10}-1 \times 10^{-8} M$ (using $100 \mu$ sample) with high selectivity over other biological molecules.
\end{abstract}

Key words: vitamin $\mathrm{B}_{12}$ (cyanocobalamin), competitive binding assays, enzyme-vitamin conjugates, vitamin tablet analyses.

Enzyme-immunoassays (EIA) are attractive alternatives to classical radioimmunoassay procedures for the detection of biomolecules at trace levels. Modern heterogeneous EIA methods are often based on the competition between the analyte and enzyme-labeled analyte molecules for antibody binding sites immobilized on a solid phase [1,2]. After appropriate separation and washing steps, the measured enzyme catalytic activity bound to the solid support is inversely proportional to the concentration of analyte in the sample. While selective antibodies have been the reagents most often used to devise such methods, we recently demonstrated the advantages of using immobilized natural binders [3-5] in place of antibodies, particularly in cases where the preparation of antibodies toward the analyte is difficult. We now report an extension of this new concept by describing a very simple solid-phase enzyme-linked method suitable for the direct determination of vitamin $\mathrm{B}_{12}$ (cyanocobalamin, $\mathrm{CNCbl}$ ).

\footnotetext{
* Current address: Kallestad Lab., Inc., 200 Lake Hazeline, Chaska, MN 55318, USA

** Current address: Department of Chemistry, University of Kentucky, Lexington, KY 40506, USA

*** To whom all correspondence should be addressed
} 
The two bioanalytical methods most often used to detect $B_{12}$ include microbiological assays $[6,7]$ and radioassay competitive binding methods [7-10]. The microbiological method is very slow (1-2 days) and yields only semiquantitative values. The competitive binding technique involves the use of a ${ }^{57} \mathrm{Co}$-cobalamin in conjunction with various vitamin $\mathrm{B}_{12}$ selective binders (R-protein, Intrinsic Factor, and Transcobalamin II) insolubilized on solid supports [7-13]. While extremely sensitive, the radioassay method is plagued by the need to use and dispose of radioactive material.

Recently [14], we introduced a new homogeneous enzyme-linked assay for vitamin $B_{12}$ based on the inhibition of glucose-6-phosphate dehydrogenase-vitamin $\mathrm{B}_{12}\left(\mathrm{G} 6 \mathrm{PDH}-\mathrm{B}_{12}\right)$ conjugates by soluble R-protein. This homogeneous method was quite rapid and selective; however, even under optimized conditions, the proposed assay could only detect $\mathrm{B}_{12}$ at levels $\geq 10 \mathrm{nM}$. In the assay described here, we report results obtained when using an immobilized form of R-protein in conjunction with similar G6PDH- $B_{12}$ conjugates. By employing a heterogeneous assay protocol, the detection capabilities of the enzyme-linked competitive binding method are improved significantly (down to $0.3 \mathrm{nM}$ ). The final assay is selective for $B_{12}$ and useful for the direct determination of $B_{12}$ in infant formula and vitamin tablets.

\section{Experimental}

\section{Apparatus}

Enzyme activities were measured with a Gilford (Oberlin, OH) Stasar III Spectrophotometer equipped with a vacuum-operated sampling system and temperature-controlled cuvette. The cuvette chamber was maintained at $30^{\circ} \mathrm{C}$. The spectrophotometer was interfaced with a Syva CP-5000 EMIT Clinical Processor.

\section{Reagents}

Porcine R-protein (non-intrinsic factor), vitamin $\mathrm{B}_{12}$, glucose-6-phosphate dehydrogenase (G6PDH) (from Leuconostoc mesenteroides), as well as all other biochemicals were obtained from Sigma Chemical Co. (St. Louis, MO).

Substrate solutions (glucose-6-phosphate, $\beta$-NAD ${ }^{+}$) were prepared in $0.050 \mathrm{M}$ Tris(hydroxymethyl)aminomethane-hydrochloric acid (Tris- $\mathrm{HCl}$ ) buffer, $\mathrm{pH} 7.8$, containing $0.10 \mathrm{M} \mathrm{NaCl}$ and $0.01 \%(\mathrm{w} / \mathrm{v}) \mathrm{NaN}_{3}$ (assay buffer). Conjugates, standards, and binding protein solutions were prepared in the same buffer also containing $0.1 \%(\mathrm{w} / \mathrm{v})$ gelatin (Tris-gel buffer). Gelatin was added to reduce non-specific adsorption of the enzyme- $B_{12}$ conjugate or analyte $B_{12}$ molecules onto the walls of the test tubes and the solid-phase $R$ protein beads. The vitamin preparations and the infant formula analyzed were commercially available and their manufacturers and compositions are listed in Table 1.

A standard stock solution of vitamin $\mathrm{B}_{12}$ was prepared by dissolving a given amount of cyanocobalamin in assay buffer. The concentration of this stock solution was determined spectrophotometrically using a molar extinction coefficient for CNCbl at $361 \mathrm{~nm}$, $E_{361}=280601 \mathrm{~mol}^{-1} \mathrm{~cm}^{-1}$. Standards solutions of $\mathrm{B}_{12}$ in the range of $10^{-11}-10^{-6} \mathrm{M}$ were prepared by diluting this stock solution with Tris-gel buffer. 
Table 1. Composition of analyzed samples

\begin{tabular}{|c|c|c|c|c|}
\hline \multirow[t]{2}{*}{ Content } & $\begin{array}{l}\text { B complex } \\
\text { with C }\end{array}$ & B complex ${ }^{b}$ & $\begin{array}{l}\text { Folic acid } \\
\text { with } B_{12}\end{array}$ & \multirow{2}{*}{$\begin{array}{l}\text { Infant }^{\mathrm{d}} \\
\text { formula } \\
(\mathrm{mg} / 5 \mathrm{fl} \mathrm{oz})\end{array}$} \\
\hline & \multicolumn{3}{|l|}{ (mg/tablet) } & \\
\hline Vitamin $\mathrm{K}$ & & & & 0.008 \\
\hline Vitamin $B_{1}$ & 50 & 50 & & 0.1 \\
\hline Vitamin $\mathrm{B}_{2}$ & 50 & 50 & & 0.15 \\
\hline Vitamin $\mathrm{B}_{6}$ & 50 & 50 & & 0.06 \\
\hline Vitamin $B_{12}$ & 0.05 & 0.05 & 0.005 & 0.00025 \\
\hline Vitamin $\mathrm{C}$ & 50 & & & 9 \\
\hline Niacinamide & 50 & 50 & & 1.05 \\
\hline Biotin & 0.05 & 0.05 & & 0.044 \\
\hline Pantothenic acid & 50 & & & 0.45 \\
\hline Choline & 50 & & & 16 \\
\hline Inositol & 50 & & & 4.7 \\
\hline Para-amino benzoic acid & 50 & & & \\
\hline Folic acid & 0.4 & 0.4 & 0.8 & 0.015 \\
\hline Protein & & & & 2220 \\
\hline Minerals & & & & $*$ \\
\hline
\end{tabular}

a Bio-genics, Woodland Hills, CA

b The Kroger Co., Cincinnati, $\mathrm{OH}$

c Makers of KAL, Inc., Woodland Hills, CA

d Similac, Ross Laboratories, Columbus, $\mathrm{OH}$

* Contains numerous inorganic salts

\section{Preparation of $\mathrm{G} 6 \mathrm{PDH}-\mathrm{B}_{12}$ Conjugate}

A G6PDH- $\mathrm{B}_{12}$ conjugate containing approximately $6.4 \mathrm{~B}_{12}$ molecules per enzyme was synthesized from monocarboxylic acid derivatives of $B_{12}$ using the procedure described in an earlier paper [14]. This conjugate possessed $83 \%$ of its original enzymatic activity following the conjugation reaction.

\section{Preparation of R-Protein Solid-Phase Reagent}

R-protein solid-phase beads were prepared by covalently attaching $0.485 \mathrm{mg}$ of R-protein to $900 \mathrm{mg}$ of commercial CNBr activated Sepharose $4 \mathrm{~B}$ particles according to the method suggested by the manufacturer [15]. Briefly, the activated gel was swollen and washed in $1 \mathrm{mM} \mathrm{HCl}$ solution (in order to remove dextran and lactose, which are added to the activated gel to preserve its activity under freeze-drying). The protein to be coupled was dissolved in coupling buffer $(0.1 \mathrm{M} \mathrm{NaHCO}, \mathrm{pH} 8.3,0.5 \mathrm{M} \mathrm{NaCl})$ and then added to the gel suspension and incubated for $2 \mathrm{~h}$. Excess protein was washed away and the remaining active groups in the beads were blocked using glycine. After the coupling was completed and the remaining active groups blocked, the excess blocking reagent and adsorbed protein were washed away by alternatively washing the beads with high and low pH buffer solutions. The solid-phase was 
finally resuspended in a $1: 5$ suspension (ratio of beads to total volume of Tris-gel buffer) and stored at $4^{\circ} \mathrm{C}$. This suspension was further diluted (1:66) with Tris-gel buffer for use as a reagent in the heterogeneous competitive binding assay.

The solid phase binding beads could be stored for at least three months without significant changes in their ability to bind G6PDH- $\mathrm{B}_{12}$ conjugates. However, attempts to regenerate (by washing with an alkaline glycine buffer, $\mathrm{pH} 12.9$ [16]) the solid-phase after use in the $\mathrm{B}_{12}$ assays resulted in beads that retained only $30 \%$ of their initial conjugate binding capacity. Thus, fresh solid-phase reagent was always used for each $B_{12}$ assay and to obtain calibration data.

\section{Heterogeneous Assays for Vitamin $B_{12}$}

The assays were carried out in a single incubation (equilibrium) mode. This was accomplished by mixing $100 \mu \mathrm{l}$ of the standard or sample solution with $100 \mu \mathrm{l}$ of a conjugate solution and $200 \mu \mathrm{l}$ of an R-protein suspension with $400 \mu \mathrm{l}$ Tris-gel buffer. After an incubation period of $2.5 \mathrm{~h}$, the beads were centrifuged and washed three times with assay buffer. One hundred $\mu$ l of each enzyme substrate, G6P $(0.10 M)$ and $\beta$-NAD ${ }^{+}(0.063 M)$, and $800 \mu l$ of assay buffer were then added and the tubes were incubated again for $2 \mathrm{~h}$. After this time, the beads were centrifuged and the absorbance of the supernatant was measured at $340 \mathrm{~nm}$.

\section{Sample Preparations and Vitamin $B_{I 2}$ Determinations}

Infant formula. Samples of the liquid infant formula were used as is or diluted 1:2 with Tris-gel buffer.

Vitamin tablets. For the folic acid with $\mathrm{B}_{12}$ vitamin preparation, 12 tablets were ground and the amount equivalent to 3 tablets was weighed and mixed with deionized $\mathrm{H}_{2} \mathrm{O}$ in a $50 \mathrm{ml}$ centrifuge tube. The solution was shaken, end to end, for $1 \mathrm{~h}$ at $4^{\circ} \mathrm{C}$. The suspension was then centrifuged four times at $2400 \mathrm{rpm}$ for $10 \mathrm{~min}$ intervals. The supernatant was transferred, after each centrifugation step, to a $100 \mathrm{ml}$ volumetric flask. The volume was then completed up to $100 \mathrm{ml}$ with deionized $\mathrm{H}_{2} \mathrm{O}$. Several dilutions of the supernatant were made with Tris-gel buffer. For the B-complex preparations (with and without Vitamin C), 10 tablets were ground together and the amount equivalent to one tablet was weighed and added to a $1000 \mathrm{ml}$ volumetric flask. The volume was completed to mark with deionized $\mathrm{H}_{2} \mathrm{O}$ and this solution was stirred for $24 \mathrm{~h}$ at $4^{\circ} \mathrm{C}$. From this sample solution, further dilutions in Tris-gel buffer were prepared.

The resulting samples were stored at $4^{\circ} \mathrm{C}$ and protected from light. These samples were analyzed according to the heterogeneous assay protocol described above, along with the standards. The unknown concentrations were estimated graphically from the calibration curve. Only the steep portion of the dose response curve was used for analytical purposes. 
For the recovery study, a concentrated infant formula solution was spiked with $100 \mu \mathrm{l}, 500 \mu \mathrm{l}$, or $1500 \mu \mathrm{l}$ of a $3.5 \times 10^{-7} M \mathrm{~B}_{12}$ standard solution. These spiked solutions were then diluted 1:5 with Tris-gel buffer. The rest of the procedure was the same as for the analysis of the unspiked infant formula.

\section{Results and Discussion}

Since the binding interaction of G6PDH- $\mathrm{B}_{12}$ and R-protein in solution previously had been found to induce inhibition of enzymatic activity [14], we initially wanted to determine whether the immobilized form of R-protein would yield an analogous effect. To investigate this, varying amounts of the solid-phase R-protein reagent were incubated for $30 \mathrm{~min}$ with a given amount of G6PDH- $\mathrm{B}_{12}$ conjugate $\left(1.25 \times 10^{-9} \mathrm{M}\right)$, in the presence of the substrates $\mathrm{G} 6 \mathrm{P}$ and $\beta$-NAD ${ }^{+}$. After centrifugation, the absorbance of the supernatant was measured and compared to that obtained for the same experiment in the absence of solid-phase R-protein (full activity). While nearly $30 \%$ inhibition was observed in the presence of excess (i. e., $30 \mu \mathrm{l}$ absolute volume) solid-phase R-protein (compared to $65 \%$ for the same conjugate when soluble R-protein is employed [14]) insignificant effects (2-4\% inhibition) were found when the amount of solid-phase R-protein equalled that normally employed in the solid-phase enzyme-linked competitive assay protocol $(2-4 \mu \mathrm{l}$; limiting reagent). Thus, we concluded that the inhibition induced by the immobilized R-protein would not cause problems when attempting to utilize G6PDH- $\mathrm{B}_{12}$ conjugates in devising a heterogeneous competitive binding assay for $\mathrm{B}_{12}$.

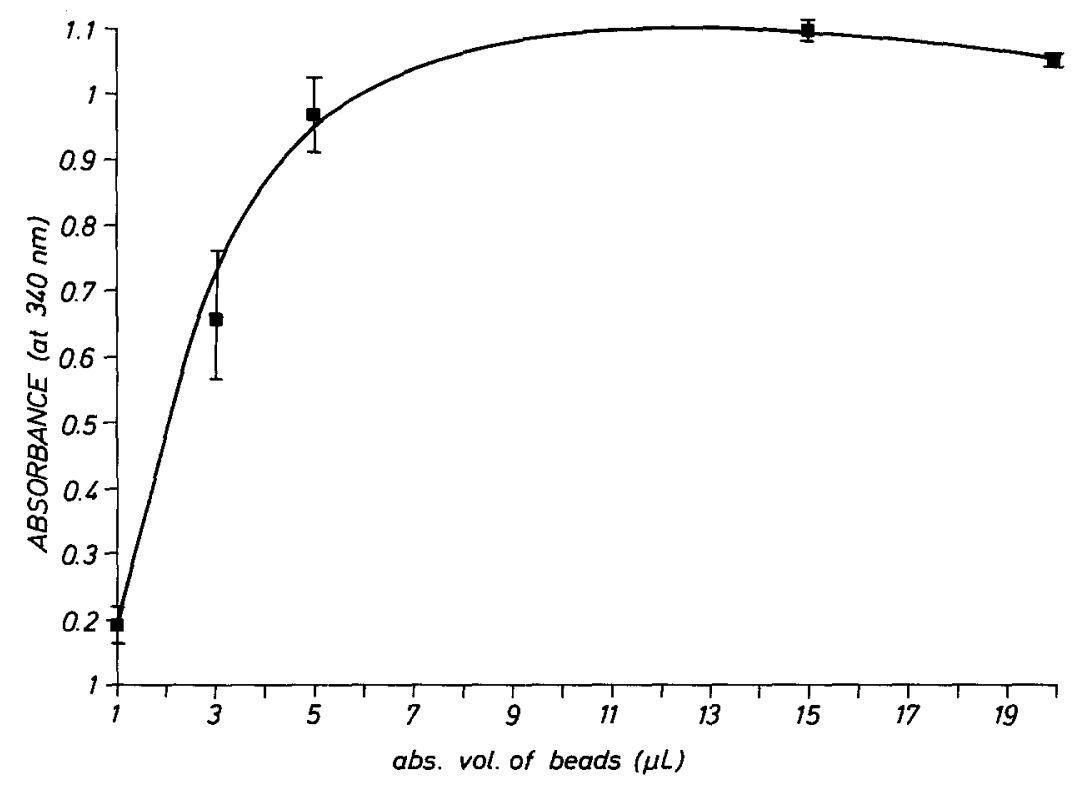

Fig. 1. G6PDH- $\mathrm{B}_{12}$ conjugate $\left(9.4 \times 10^{-10} M\right)$ binding as a function of increasing immobilized R-protein solid-phase (volume refers to settled volume of R-protein beads). Data points are average of two determinations 
In order to determine the capacity of the solid-phase R-protein for binding the G6PDH- $\mathrm{B}_{12}$ conjugate (not the actual binding constant), varying amounts of the $\mathrm{R}$-protein reagent were incubated with a fixed level of conjugate. After $3 \mathrm{~h}$, the activity of conjugate bound to the solid phase was determined. Fig. 1 illustrates the results of such an experiment. At higher levels of R-protein beads, the amount of bound conjugate activity levels off to about $40 \%$ of that initially added to the reaction mixture. Given that at high levels of R-protein beads there is also some inhibition of the conjugate (see above discussion), we estimate that about $60 \%$ of the starting G6PDH$\mathrm{B}_{12}$ conjugate can be bound by the immobilized $\mathrm{R}$-protein. The remainder of the conjugate molecules probably cannot bind to the solid-phase due to steric factors (i. e., their covalently bound $\mathrm{B}_{12}$ molecules are in regions inaccessible for binding to the solid phase). Generally, for the heterogeneous competitive binding assays, we chose an amount of solid phase R-protein which fell on the steep portion of the binding curve (e.g. $1-3 \mu$ l absolute bead volume) (see Fig. 1).

The kinetics of the binding of G6PDH- $\mathrm{B}_{12}$ to immobilized R-protein was also examined (Fig. 2). We observed that binding of the conjugate to the solid phase continues to increase somewhat, even after a $3 \mathrm{~h}$ equilibration period. However, the rate of binding is significantly slowed after the first $2 \mathrm{~h}$ and thus, in subsequent competitive binding assays, we chose a $2.5 \mathrm{~h}$ time period for all incubations between the conjugate, immobilized binder, and standards or samples. Interestingly, in related work [5], we observed that the overall kinetics of conjugate binding are enhanced when the solidphase has lower levels of protein coverage. Therefore, in the present effort,

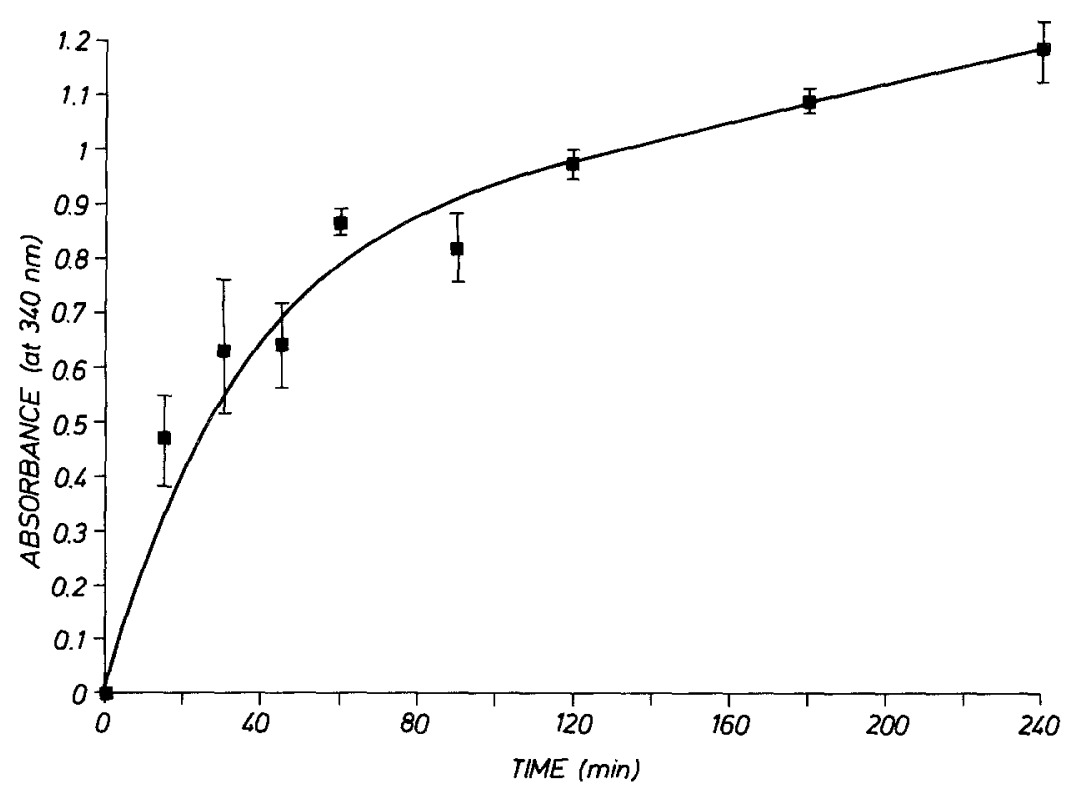

Fig. 2. G6PDH- $\mathrm{B}_{12}$ conjugate $\left(1.88 \times 10^{-9} M\right)$ binding to R-protein beads ( $4.5 \mu$ l absolute bead volume) as a function of increasing incubation time. Data points are average of two determinations 


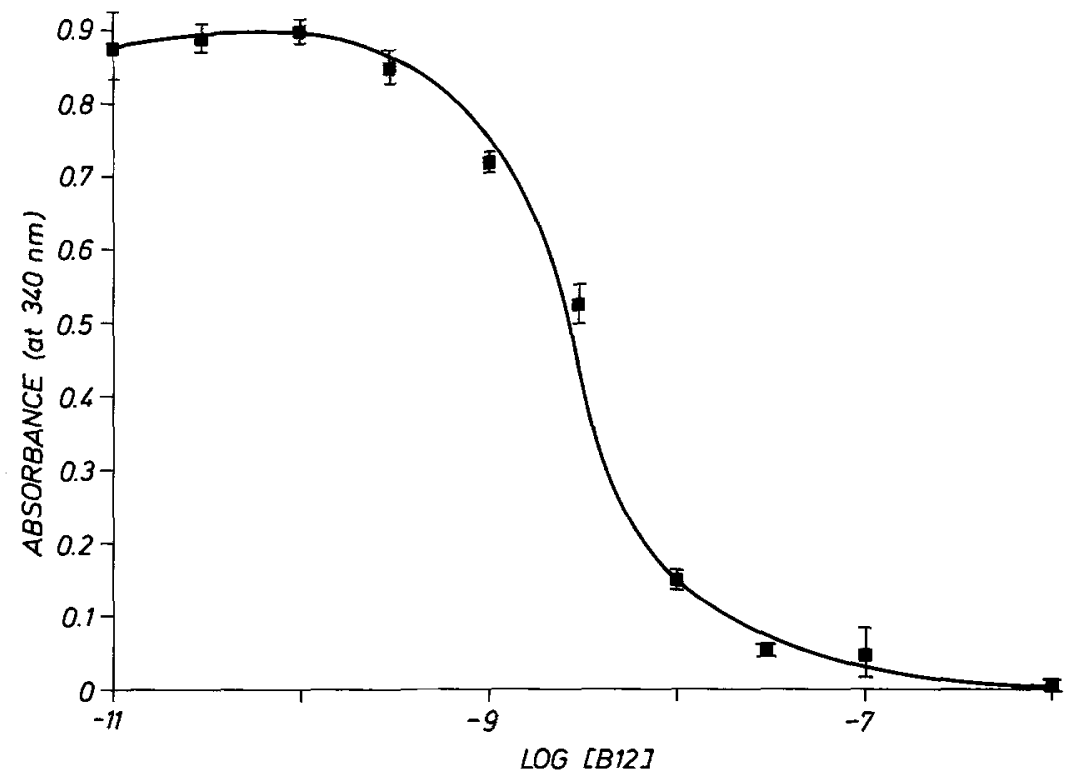

Fig. 3. Typical competitive binding dose-response curve toward $\mathrm{B}_{12}(M)$ using $1.9 \times 10^{-9} M$ G6PDH- $\mathrm{B}_{12}$ conjugate and $1.5 \mu \mathrm{l}$ absolute bead volume of solid-phase R-protein. Data points are average of two trials

we purposely prepared our solid-phase reagent using high mass ratios of Sepharose beads to R-protein.

Fig. 3 shows a typical $B_{12}$ dose-response curve obtained using the various reagents in a competitive binding assay protocol. The detection ranges, steepness of the curves, and detection limits vary depending on the concentrations of reagents used. To obtain optimized detection limits (Fig. $3 ; 3 \times 10^{-10} M \mathrm{~B}_{12}$ in sample) low levels of conjugate $\left(1.90 \times 10^{-9} M\right)$ and binder ( $1.5 \mu \mathrm{l}$ absolute volume) were employed. Although bound enzyme activities could be monitored using shorter incubation times, we chose a $2 \mathrm{~h}$ time period to improve the precision of the method (i.e., longer reaction times allow for slight differences in the time between reagent addi-

Table 2. Results for the determination of $B_{12}$ in various samples

\begin{tabular}{lcc}
\hline Sample & Found $^{\mathrm{a}}$ & Claimed \\
\cline { 2 - 3 } & $\mu \mathrm{g} /$ tablet \\
\hline B complex with C & $45 \pm 2$ & 50 \\
B complex & $46 \pm 8$ & 50 \\
Folic acid with $\mathrm{B}_{12}$ & $4.9 \pm 0.3$ & 5.0 \\
\hline Infant formula & $4.2 \pm 0.4 \mathrm{nM}$ & $2.5 \mathrm{nM}$ \\
\hline
\end{tabular}

${ }^{a}$ Average of four determinations ( \pm std. dev.) for vitamin preparations and six determinations ( \pm std. dev.) for infant formula 
tions, a situation which occurs when working with a large number of assay tubes).

The precision, selectivity, and ultimate analytical utility of the proposed solid-phase assay was evaluated by determining the $B_{12}$ content of various commercial vitamin and infant formula preparations (see Tables 1 and 2). Results obtained for the vitamin tablets were in good agreement with the manufacturer's claims. This agreement, even when $B_{12}$ is the minor component, illustrates that the method offers high selectivity over other common vitamins. Results for the infant formula were substantially higher than the labeled values. However, according to the manufacturer, the difference between minimum (labeled) and actual determined values can be quite high to ensure an adequate shelf-life for the product. Indeed, subsequent analytical recovery studies using the protein-based infant formula preparation (Table 3) yielded satisfactory accuracy, suggesting that the method can be used for direct $B_{12}$ measurements in rather complex samples.

Attempts to use the existing assay for measurements of serum $B_{12}$ levels were not undertaken since physiological concentrations of $\mathrm{B}_{12}$ fall at or below the detection limits of the new enzyme-linked method [7]. The detection limits obtainable in the enzyme-linked method appear to be restricted by the binding affinity of the immobilized R-protein toward the enzyme-labeled conjugate and analyte $B_{12}$ molecules. Although previous workers have found that radioactive $B_{12}$ binds to immobilized R-protein with high affinity, as suggested by low detection limits on competitive radioassay [13, 17], using a Scatchard analysis method, we found that the G6PDH- $\mathrm{B}_{12}$ conjugate employed in this work bound to our R-protein solidphase with an affinity constant of approximately $3.4 \times 10^{8} M^{-1}$ [18]. This value is nearly 3 orders of magnitude lower than that reported $\left(3 \times 10^{11}\right.$ $M^{-1}$ ) for the binding of radioactive $\mathrm{B}_{12}$ with a similar R-protein solid-phase [19]. Thus, steric effects owing to the bulkiness of the $B_{12}$ conjugate and/or the specific spatial orientation of the immobilized R-protein may be contributing to this low value. Improved binding of the enzyme conjugate to the solid-phase, and consequently better competitive binding assay detection capabilities may be achieved by replacing $\mathrm{R}$-protein with a different natural $B_{12}$ binder. Indeed, preliminary studies using immobilizing intrinsic factor are now in progress [18]. However, since intrinsic factor is more selective in its binding (i.e., it can differentiate among the mono-

Table 3. Results from recovery studies for the addition of $\mathrm{B}_{12}$ to infant formula

\begin{tabular}{llll}
\hline Sample & \multicolumn{2}{l}{ Vitamin $\mathrm{B}_{12}(\mathrm{nM})$} & \multirow{2}{*}{ Recovery (\%) } \\
\cline { 2 - 3 } & Added & Total found $^{\mathrm{a}}$ & \\
\hline 1 & 2.09 & 1.94 & 93 \\
2 & 3.33 & 3.18 & 96 \\
3 & 4.58 & 4.62 & 101 \\
\hline
\end{tabular}

a Average of two determinations 
carboxylic acid isomers of $\left.B_{12}[19,20]\right)$, synthesis of new conjugates prepared with only the " $e$ "-monocarboxylic acid derivative of $\mathrm{B}_{12}$, rather than a mixture of monocarboxylic acids, will be required.

Acknowledgements. The authors gratefully acknowledge support of this work by the National Science Foundation (Grant \# 8506695).

\section{References}

[1] D. Monroe, Anal. Chem. 1984, 56, 920A.

[2] A. Voller, D. E. Bidwell, in: Alternative Immunoassay (W. P. Collins, ed.), Wiley, New York, 1985, pp. 77-86.

[3] L. G. Bachas, P. Lewis, M. E. Meyerhoff, Anal. Chem. 1984, 56, 1723.

[4] L. G. Bachas, C. D. Tsalta, M. E. Meyerhoff, Biotechniques 1986, 4, 42.

[5] G. S. Cha, M. E. Meyerhoff, Anal. Biochem. 1988, 168, 216.

[6] D. L. Mollin, B. B. Anderson, J. E. Bauman, Clin. Haematol. 1976, 5 (3), 52h.

[7] I. Chen, M. I. Sperling, L. A. Heminger, in: Methods in Clinical Chemistry (A. J. Pesce, L. A. Kaplan, eds.), Mosby, St. Louis, MO, 1987, pp. 569-573.

[8] K. S. Lau, C. Gottlieb, L. R. Wasserman, V. Herbert, Blood 1965, 26, 202.

[9] G. Tibbling, Clin. Chim. Acta 1969, 23, 209.

[10] M. Caeska, U. Lundkuist, Clin. Chim. Acta 1971, 32, 339.

[11] E. Nexo, P. Gimsing, Scand. J. Chim. Lab. Invest. 1981, 41, 465.

[12] I. W. Chen, E. B. Silberstein, H. R. Maxon, M. Sperling, E. Barnes, J. Nucl. Med. 1981, $22(5), 447$.

[13] N. P. Kubasik, M. Ricotta, H. E. Sine, Clin. Chem. 1980, $26(5), 598$.

[14] C. D. Tsalta, M. E. Meyerhoff, Anal. Chem. 1987, 59, 837.

[15] Affinity Chromatography, Principles and Methods, Pharmacia Fine Chemicals, Piscataway, NJ, 1979.

[16] R. Gräsbeck, U. H. Stenman, L. Puutula, K. Visuri, Biochim. Biophys. Acta 1968, 158, 292.

[17] M. Muir, I. Chanarin, Br. J. Haematol. 1983, 53, 423.

[18] C. D. Tsalta, $P h$. D. Dissertation, University of Michigan, 1987.

[19] E. Hippe, F. Haber, H. Olesen, Biochim. Biophys. Acta 1971, 243, 75.

[20] D. L. Anton, H. P. C. Hogenkamp, T. E. Walker, N. A. Matwigoff, J. Am. Chem. Soc. 1980, 102, 2215.

Received September 10, 1987. Revision December 7, 1987. 